DOI: https://doi.org/10.32839/2304-5809/2020-12-88-73

УДК 378.147:1

Подопригора А.O.

Приватний вищий навчальний заклад «Київський університет культури»

\title{
ПРОБЛЕМА ВИХОВАННЯ АКТОРА В СУЧАСНІЙ ВІТЧИЗНЯНІЙ ОСВІТІ
}

\begin{abstract}
Анотація. У статті визначено актуальність, зроблено короткий огляд існуючих досліджень та публікацій з проблематики виховання сучасного актора. Зроблено аналіз деяких аспектів та складових існуючої системи виховання актора в Україні. Аналізується та підкреслюється важливість удосконалення існуючої системи виховання актора та пошуки й впровадження нових альтернативних інноваційних методик. Розкривається значення особистих творчих якостей актора для успішної професійної діяльності. Проаналізовано сучасну систему професійної підготовки актора та психолого-педагогічні основи освітнього процесу у системі виховання актора.
\end{abstract}

Ключові слова: театральне мистецтво, актор, професійні якості, акторська майстерність, акторська школа, система виховання актора, українська школа виховання актора.

Podoprygora Anna Kyiv University of Culture

\section{PROBLEMS OF ACTORS' TRAINING UP-TO-DATE EDUCATIONAL SYSTEM OF OUR COUNTRY}

Summary. Actual task of the science of our country's to identify and realize the specific features of the educational function in the process of training the specialist in sphereofactingart and searching the optim always as for the further development of all stages of domestic art education. The undergone analysis of the literature in philosophy, psychology, drama, art, culturology and methodology gave an opportunity to come to the conclusion that only some important aspects of the outlined problem had been researched and analyzed but the problem of actors' training had not been studied enough both in theoretical and practical aspects and that fact stipulated the research of mentioned above problems. The aim of the article is to reveal some principal aspects of modern actors'training, investigate and analyze up-to-date tendencies and directions in order to find out the solution of the problem. At present, the current task of our science is to reveal and realize the specific features of the process of training the specialists in sphereofactingart, thorough analysis and selection of the previous researches, searching and introducing the innovative methods and techniques. Basing on those ones it could be possible to find out the optimal ways for the further art education development. Nowadays, it is necessary to make a new national acting school in order to respond modern tendencies and current situations which have been occurred in Ukrainian art, art education, world social processes. The dominant feature of that process should become the strength of the actor's personality. The goal of educational process in the universities of arts is to train the specialists being ready to perform art-creative, cultural-instructive, performing and managerial activities and requires to form their readiness for given specialty and professional realization. Creative young people require changes in the pedagogical-educational process to be done. They are striving for innovations, creative experiments, creative search and trying to introduce something new, innovative into theatrical art. All mentioned above allows us to make the conclusion that in the current conditions the further theatrical art development and modern Ukrainian actors' professional training development shall be performed and designed in the context of making modern, advanced, scientifically-grounded theatrical school basing on the traditions of Ukrainian theatrical culture. That school should be built considering both theory and creative practice.

Keywords: theatrical art, actor, professional qualities, acting skills, actingschool, actor education system, Ukrainian school of actor's education.

$\Pi$ остановка проблеми. Сучасний світ перебуває в активному процесі становлення глобальної організації соціокультурного простору, який об'еднуе народи й країни, що існують на різних рівнях розвитку національної культури, мають найрізноманітніші традиції та релігійні переконання. Це ставить перед освітянами, науковцями ві діячами театрального мистецтва нові завдання, які необхідно усвідомлювати та вирішувати.

Актуальним завданням вітчизняної науки $€$ виявлення й осмислення специфріки виховної фонкції в процесі підготовки фрахівців у галузі театрального мистецтва та пошук оптимальних шляхів подальшого розвитку усіх ланок вітчизняної мистецької освіти.

Актуальність вирішення окреслених питань відображено в державних нормативних документах (Закони України «Про освіту», «Про вищу освіту», «Про культуру», Указ Президента України «Про стратегію національно-патріотичного виховання дітей та молоді на 2016-2020 рр.).

Аналіз останніх досліджень та публікацій. Проблеми підготовки та виховання актора в сучасній науково-методичній літературі досліджено, висвітлено і проаналізовано багатьма вченими, педагогами, акторами, режисерами, що знайшло своє відображення у вирішенні ши- 
рокого кола теоретичних і практичних завдань, a саме: розвитку мистецтва театру та теоретичних основ фрахової підготовки актора до профресійної діяльності (А. Анікст, С. Мокульський, I. Рапопорт, Н. Рождественська, Ю. Сагіна, К. Станіславський, В. Тополевський, В. Топорков, К. Чепеленко, С. Юр'єв та ін.); підготовки майбутнього актора до профресійної діяльності (Б. Брехт, П. Брук, С. Вахтангов, Л. Волков, С. Гіпіус, Є. Гротовський, П. Єршов, Б. Захава, М. Кнебель, 3. Корогодський, Г. Крісті, Л. Курбас, Д. Лівнев, В. Мейерхольд, В. Немирович-Данченко, К. Станіславський, Л. Цукасова, М. Чехов та ін.); профресійного спілкування як складової фахової діяльності актора (А. Брудний, В. Дибо, М. Каган, О. Копалова, І. Кулічков, О. Леонтьєв, Р. Штейнер та ін.).

Сучасні концептуальні підходи до театрального мистецтва, зокрема театральної педагогіки (науки й мистецтва виховання актора), знайшли своє відображення у різноманітних аспектах: як засіб удосконалення педагогічної майстерності (В. Абрамян, М. Барахтян, I. Гончаров, Т. Гончарова, А. Сршова, І. Зязюн, І. Синиця, Н. Сулаєва, С. Швидка); як засіб розвитку творчого потенціалу (Ю. Азаров, Р. Баталов, В. Загв'язинський, Г. Падалка, Л. Рувинський); як засіб розвитку духовності (П. Сршов, І. Зязюн, Г. Переухенко, Л. Чуриліна); як засіб розвитку мовленнєвої виразності (В. Абрамян, Ю. Слісовенко, А. Капська, Г. Сагач).

На значимості практики фрахівця актора чи режисера під час здобуття художньо-мистецької освіти акцентують увагу Є. Ганелін, I. Генералова, В. Кісін, М. Крапівка, М. Левченко, Л. Некрасова, Т. Полякова, Н. Чечель та ін.

Виділення невирішених раніше частин загальної проблеми. Проведений аналіз філософрької, психологічної, культурологічної, театрознавчої, мистецтвознавчої та методичної літератури дав можливість зробити висновок про те, що досліджено та проаналізовано лише окремі важливі аспекти означеної проблеми, проте проблема виховання актора у вітчизняній сучасній освіті ще не достатньо повно досліджена та розкрита як в теоретичному так й в практичному аспектах, що й обумовило звернення до даної проблематики.

Мета статті полягае у розкритті основних аспектів проблеми виховання сучасного актора та дослідженні і аналізі сучасних тенденщій і напрямків у вирішені даної проблеми.

Виклад основного матеріалу дослідження. Театральне мистецтво - це специфічний вид мистецької діяльності, який поєднуе в собі можливості багатьох художніх засобів та експресії; воно створює певні художні образи, розвиває культуру мовлення, образне мислення, регулює поведінку; сприяє розвитку асоціативної пам'яті, художньої уяви, а також впливає на внутрішній світ людини.

Синтетична природа сценічного мистецтва робить його мультикультурним та міждисциплінарним явищем. У сценічному дійстві використовуються виражальні засоби всіх основних видів мистецтва. Театр-мистецтво колективне, що потребуе злагоджених дій та порозуміння різних творчих особистостей» [3, с. 3].
Театральне мистецтво характеризується нерозривним зв'язком із театральним освітою. Модель репертуарного театру повинна забезпечити не тільки можливість активного співробітництва театрів і навчальних закладів в освітньому процесі, а й неформальну, фрактично безперервну освіту в театральних трупах у процесі практичної творчої діяльності.

Репертуарний театр із постійною трупою здатний забезпечити спадкоємність акторського мистецтва. Актор, який отримав основи майстерності в спеціалізованому театральному закладі освіти, по-справжньому опановуе професію тільки в театрі, в роботі з режисерами, з майстрами сцени. Актор має пізнати особливості театру різних джерел, різнопланову театральну антропологію, ритуали й акції різних театральних груп.

У Стандарті вищої освіти України для спеціальності «Сценічне мистецтво» освітнього рівня «бакалавр» в описі предметної області вказується: «Сфера сценічного мистецтва - унікальна та універсальна модель пізнання світу, людської комунікації [3, с. 3].

Розвиток сучасного українського суспільства в напрямку інтеграції до Свропейського культурного простору гостро потребуе талановитих та конкурентоспроможних майстрів у галузі мистецтва, а саме, акторів театру і кіно з високим рівнем фрахової освіти.

Державний стандарт вищої освіти України (Галузь знань «02 Культура і мистецтво», Спеціальність «026 Сценічне мистецтво») подає перелік компетентностей, якими має володіти фрахівець сценічного мистецтва. Серед них: здатність до оперування специфічною системою виражальних засобів (пластично-зображальними, звуковими, акторсько-виконавськими та ін.); здатність до вибору відповідних творчому задуму засобів мистецького (сценічного) висловлювання [3, с. 4].

А оскільки актор як фрахівець є носіем специфіки театру, то його професійні вміння сприяють вирішенню нагальних суспільних питань і є свідченням його профресійної компетентності.

I тому актуальним завданням вітчизняної науки на сучасному етапі є виявлення й осмислення специфіки процесу підготовки фрахівців у галузі театрального мистецтва, ретельний аналіз і відбір надбань минулих років та пошук і впровадження інноваційних сучасних методик та технологій, на основі яких стає можливим пошук оптимальних шляхів подальшого розвитку вітчизняної мистецької освіти.

Акторське мистецтво - це безперервна робота душі й розуму. Сьогодні визначальною у формуванні особи актора є діалектична єдність двох складових: збереження кращих традицій, фрундаменту школи і безперервного експериментатора, відкритості світу, часу. «Творчі зіткнення юності і зрілості, відваги і розумного консерватизму - основа всякої школи» [2, с. 15].

Виховання і формування особистості актора нового тисячоліття неможливе без високоякісної гуманітарної і профресійної підготовки. Вивчення та ретельний аналіз існуючих методик роботи 3 актором К. Станіславського, В. НемировичаДанченко, Л. Курбаса, В. Мейерхольда, С. Вахтангова, М. Чехова, М. Крушельницького, П. Єршова, Г. Товстоногова та інших дав можливість 
зробити висновок про те, що сьогодні в арсеналі театрального педагога мають бути різні методи, методики і техніки, щоб актор міг вибирати свій шлях роботи над роллю, близькій до його індивідуальності. Сьогодення вимагає від сучасного актора бути готовим не лише до роботи над роллю в театрі, а i до життя, а саме розвивати свої духовні потреби піднімати свій професійний та культурний рівень.

Ще у кінці XIX століття діячі театру говорили про штучне виховання актора і режисера. Колективна природа театру вимагає виховання і розвитку індивідуальності актора в умовах колективної творчості, уміння підпорядковувати свою творчість задуму режисера. Сьогодні як і раніше актуальна думка про фрормування особистості актора, виховання почуття ансамблю, прищеплення етичних норм.

Однією 3 найважливіших проблем театральної освіти і виховання є проблема навчання актора самостійності в роботі над собою, методиці роботи над роллю в п'єсі будь-якого жанру і стилю.

Сьогодні потрібно створити нову національну акторську школу як відповідь на сучасні виклики і актуальні ситуації, що склалися в українському мистецтві, мистецькій освіті, у світових суспільних процесах. Домінантою у цьому процесі має стати сила особистості актора.

Метою освітнього процесу у творчому навчальному закладі є підготовка фрахівців до художньотворчої, культурно-просвітницької, виконавської та організаційно-управлінської діяльності, що вимагає формування готовності до даної профресії і фоахової реалізації.

М. Заньковецька, П. Саксаганський, М. Кропивницький, I. Карпенко-Карий, О. Курбас, Г. Юра, М. Крушельницький, Л. Сердюк та інші діячі української сцени сорормували основні засади виховання актора українського національного театру, розробили методики української акторської школи.

М. Старицький, М. Крушельницький, О. Курбас, Г. Юра, Л. Сердюк, В. Неллі та інші відомі театральні педагоги не лише перенесли досягнення профресійної театральної школи на національний грунт, а й віднайшли можливості розвивати їі та вдосконалювати у своїй практичній діяльності в українській школі виховання актора [1, с. 27].

Стосовно щодо системи виховання, то слід зазначити, що система виховання - це сукупність взаємопов'язаних цілей і принципів організації виховного процесу, методів і прийомів їх поетапної реалізації в межах певної соціальної структури (сім'ї, школи, культурно-дозвіллевих закладів, спеціалізованих (творчих) навчальних коледжів та ВНЗ культурно-мистецького профілю, держави) та логіки виконання соціального замовлення [6, с. 42].

К. Станіславський зазначав, що систему виховання не можна завчити на пам'ять, їі можна засвоїти, увібравши в себе так, щоб вона увійшла в плоть і кров, стала другою натурою, органічно злилася раз і назавжди, породила артиста для сцени [4].

Слід підкреслити, що видатні митці українського театру внесли свій значний внесок у формування та розвиток школи акторської майстерності і нині ми маємо певний фрундамент режисерської та педагогічної теоретичної думки. Значний пласт педагогічно-виховних настанов для майбутніх фрахівців українського театрального мистецтва містить творча літературна спадщина Л. Курбаса, М. Крушельницького, Г. Юри, I. Карпенка-Карого.

Відкриття К. Станіславським на початку XX сторіччя свідомих шляхів до підсвідомого в мистецтві актора істотно вплинуло на розвиток та вдосконалення методик виховання актора [4].

Необхідно відзначити, якщо ще на межі XX XXI ст. специфіка фрахової освіти в театральній галузі України та Росії була майже ідентичною, що зумовлювало доречність застосування в педагогічній практищі теоретично-методичного доробку митців обох країн, проте, сучасні глобалістичні тенденції в сфрері української освіти породжують певні специфічні проблеми та відмінності.

Але слід наголосити на тому, що порівняно 3 теоретичним осмисленням специфіки російської театральної школи, надбання українського теоретичного, методичного й практичного доробку є ще незначним і потребує вітчизняних наукових розвідок та висвітлення.

Актуальним завданням вітчизняної науки $€$ виявлення й осмислення специфіки виховної фрункції в процесі підготовки фрахівців у галузі театрального мистецтва, на основі чого є можливим пошук оптимальних шляхів подальшого розвитку вітчизняної мистецької освіти.

Сучасна система навчання профресійного актора є наслідком пошуків, експериментів, теоретичних та емпіричних досліджень протягом останніх років. За цією системою навчались сотні людей, які згодом, в справі свого життя зайняли лідируючі позищії. Багато із них залишились в мистецтві i створили власні сучасні театральні осередки, театри-лабораторії, експериментальні театри, театри-студії, заснували міжнародні та всеукраїнські театральні фестивалі, або працюють у галузі театрального мистецтва як аналітики, дослідники, критики, театрознавці, культурологи.

Всіх цих людей об'єднуе те, що вони не схожі один на одного, що вони обрали свій шлях, свій стиль, своє обличчя. Проте всі вони зазначають, що першою сходинкою до їх сучасної творчої діяльності була саме система акторського виховання.

Проте сьогодні головною метою $є$ створення і розвиток принципово нової, сучасної вітчизняної акторської школи. Школи у самому широкому розумінню цього слова: від початкової акторської освіти, в якій головне - це власна творча особистість людини, до грунтовної світоглядної концепції. Крім того, під наявністю школи розуміеться включення усіх ланок підготовки фрахівця в акторській продресії.

В цьому контексті обов'язковим $є$ уважне вивчення досвіду таких універсальних, тобто справжніх педагогів-режисерів минулого, як В. Шекспір, Мольер, В. Немирович-Данченко, К. Станіславський, М. Кропивницький, I. Карпенко-Карий, В. Неллі, Г. Юра, Д. Алексідзе, М. Хохлов, В. Карасьов та інші. Очолюючи театри як художні керівники, вони займались виховною та педагогічною роботою.

На характер творчого виховання актора на сучасному етапі впливає декілька фракторів, цей характер зумовлюеться, зокрема, особливостями 
та потребами як державних так і альтернативних, незалежних, експериментальних театрів, студій, ВНЗ, а іноді цей характер залежить від певних творчих особистостей.

Тільки у театральній школі-майстерні, грунтованій на здорових етичних, естетичних й художніх принципах, можна отримати повноцінне театральне виховання, тільки в такій школі можна навчитися не одній «техніці», але і «методу», «у свій способі робити театр».

Дж. Стрелер, згадуючи учбову сцену Міланської академії драматичного мистецтва, стверджував, що «там був вже увесь театр, нехай в зменшеному вигляді, але увесь» [5, с. 104].

3 іншого боку, змін у педагогічно-виховному процесі вимагає й творча молодь, котра прагне до інновацій, до творчих експериментів, креативного пошуку і намагається внести щось нове, інноваційне у театральне мистецтво.

Сучасна культурно-мистецька освіта, як один із фрундаментальних і стійких компонентів оновлення повинна спрямовувати свої сили і висувати нові вимоги щодо підготовки спеціалістів не тільки з галузевими базовими знаннями, а й з розвиненими творчими здібностями, які формують випускника як індивідуальну особистість, яка має потенціал творчої людини, конкурентно-спроможної, що зможе адаптуватися до різних пропозицій, умов та обставин для вирішення сощіальних і культурних задач, які постають перед сучасним суспільством та виробляти оригінальні ідеї.

Спеціаліст, який має неординарне бачення та особливий, нестандартний підхід до рішення профресійних завдань, завжди залишаеться затребуваним у галузевій діяльності.

Все це дозволяе зробити висновок про те, що в сучасних умовах подальший розвиток театрального мистецтва і розвиток професійного виховання сучасного українського актора потрібно розвивати і спрямовувати в контексті побудови сучасної, передової, науково обгрунтованої театральної школи на базі традицій української театральної культури. Підгрунтям такої школи повинна бути не тільки теорія, а й безпосередня творча практика.
В системі акторської освіти та виховання на сучасному етапі існують певні проблеми, які потрібно вирішувати, враховуючи всі виклики часу.

Сьогодні відбувається руйнація досконалого відбору студентів акторського фраху, зневага що до їх психологічного типу, психічних станів та емоційності, усталеного характеру, котрий вже $є$ сфрормованим, байдужість до психології мистецтва загалом і психології акторського мистецтва зокрема.

Сучасна система профресійної підготовки та виховання актора повинна активно використовувати психолого-педагогічні основи освітнього процесу у системі виховання актора.

Висновки та перспективи подальших досліджень. Отже, все вище викладене дозволяє зробити наступні висновки:

- аналізуючи проблему української школи виховання актора у контексті історико-педагогічного досвіду, науково-творчого доробку вчених, дослідників, театральних діячів, ми бачимо, що у сфрері театральної педагогіки ще недосконало використовуеться та застосовуеться на практиці весь арсенал, який містить у собі система виховання актора;

- унікальність і сила українського театру полягає у його емоційності, щирості, декоративності, пластичній виразності, музичності, високій духовності, гуморі і все це необхідно прищеплювати в педагогічно-виховному процесі майбутнім акторам і залучати їх до продовження найкращих традицій української театральної школи;

- потрібно забезпечити динамічний розвиток театральної справи як у традиційних для України формах, так із використанням інноваційних підходів, адаптації світового досвіду в цій сдрері.

Ми вважаємо, що проблеми розвитку української школи виховання актора та пошук нових едективних та інноваційних методик залишаються актуальними і потребують подальшого вивчення та дослідження.

Дана публікація не вичерпуе всіх аспектів зазначеної проблеми і потребує подальших наукових розвідок та досліджень, результати яких будуть висвітлені у наступних наукових публікаціях.

\section{Список літератури:}

1. Акторська майстерність корифеїв : Збірник статей / Упоряд. : І. Волошина. Київ : Мистецтво, 1973.184 с.

2. Лапина Г. Образование и искусство. Театральная жизнь. 2000. № 8. 258 с.

3. Стандарт вищої освіти України. Галузь знань 02 Культура і мистецтво, спеціальність 026 Сценічне мистецтво. URL: www.mon.gov.ua/.../Освіта/standart/.../026-sczenichne-mistecztvo...

4. Станіславський К.С. Зібрання творів : У 9 т. М.: Мистецтво, 1988. Т. 1. Мое життя в мистецтві. URL: www.teatr-lib.ru/Library/Stanislavsky/My_life//Коммент

5. Стрелер Дж. Театр для людей. Москва : Радуга, 1984. 310 с.

6. Тофтул М.Г. Сучасний словник з етики. Житомир : Вид-во ЖДУ ім. І. Франка, 2014. 416 с.

\section{References:}

1. Aktorskamaysternistkoryfeiv: Zbirnyk statey [Leading figures' acting techniques] / Uporyad.: I. Voloshina. Kyiv: Mystetstvo, 1973. 184 p.

2. Lapina G. (2000) Obrazovanie i iskusstvo [Education and art]. Teatralnaya zhuzn, no. 8, 258 p.

3. Standartv yshchoi osvity Ukrainy. Galuzznan'02 Kultura i mystetstvo, spetsialnist 026 Stsenichne mystetstvo [Standard of higher education of Ukraine. Branch of knowledge 02, Culture and arts, specialty Performing Art]. URL: www.mon.gov.ua/.../Ocвiтa/standart/.../026-sczenichne-mistecztvo...

4. Stanislavskii K.S. (1988) Zibrannya tvoriv: U 9 t. M.: Mystetstvo. T. 1. Moe zhyttya v mystetstvi [My life in art]. URL: www.teatr-lib.ru/Library/Stanislavsky/My_life//Komment

5. Streler Dzh. (1984) Teatr dlya lyudey [Theater for people]. Moskva: Raduga, $310 \mathrm{p}$.

6. Toftul M.G. (2014) Suchasnyi slovnyk z etiki [Modern dictionary in ethics]. Zhytomir: Vud-vo ZhDU im. I. Franka, 416 p. 